\title{
Role of water infrastructure programs for family farmers in strengthening adaptive capacities to climate change: lessons from the Cisterns Program in Semi-arid Brazil
}

\author{
Papel dos programas de infraestrutura hídrica para \\ agricultores familiares no fortalecimento das \\ capacidades adaptativas às mudanças climáticas: \\ lições do Programa Cisternas no Semiárido Brasileiro
}

Patrícia S. Mesquita ${ }^{1}$

Louise Cavalcante ${ }^{2}$

${ }^{1}$ Phd in Sustainable Development, Post-Doctoral Researcher, Project INCT-Odisseia, Centro de Desenvolvimento Sustentável, Universidade de Brasília, Brasília, Brazil E-mail: patriciasmesquita@gmail.com

${ }^{2}$ Masters in Sustainable Development, Phd Student in Public Administration and Policy Wageningen University, Wageningen, NL, and Associate Researcher at the Centro de Desenvolvimento Sustentável, Universidade de Brasília, Brazil E-mail: louise.cavalcantedesouzacabral@wur.nl

\begin{abstract}
The semi-arid region of Brazil, marked by low human development indicators, has historically suffered from water scarcity, being the focus of public policies to reduce socioeconomic, water, and climatic vulnerabilities for more than a century. Among the recent initiatives, the Cisterns Program stands out as an attempt to guarantee water and food security for family farmers through the construction of social technologies for water storage, such as cisterns production. Thus, the research objective was to analyse the perception of farmers and institutional actors involved with the Program about the impact of the 2011-2018 drought on the functioning of cisterns and to discuss how water infrastructure programs can improve the adaptive capacity of farmers affected by climate change. Through semi-structured interviews with institutional actors at the regional/national level and with farmers in semi-arid Brazil in the years of $2017 / 2018$, the results indicate that access to the social technology seems to strengthen the relationship between water and food security, and the specific capacity of farmers in dealing with climatic risks. We conclude with lessons and recommendations from the Brazilian experience that can be useful for actors from other semi-arid regions involved in water infrastructure programs.
\end{abstract}

Keywords: Brazilian semi-arid. Drought. Water. Cisterns. Climate change. Adaptation. 


\section{RESUMO}

A região semiárida do Brasil, uma região marcada por baixos indicadores de desenvolvimento humano, tem sofrido historicamente com a escassez de água, sendo há mais de um século o foco das políticas públicas para reduzir as vulnerabilidades socioeconômicas, hídricas e climáticas. O Programa de Cisternas se destaca como uma tentativa de garantir a segurança hídrica e alimentar dos agricultores familiares por meio da construção de tecnologias sociais de armazenamento de água, como a cisterna de produção. O objetivo da pesquisa foi analisar a percepção dos agricultores e atores institucionais envolvidos com o Programa sobre o impacto da seca de 2011-2018 no funcionamento das cisternas e discutir como os programas de infraestrutura hídrica podem melhorar a capacidade de adaptação dos agricultores afetados pela mudança climática. Por meio de entrevistas semiestruturadas com atores institucionais em nivel regional/nacional e com agricultores do semiárido nos anos 2017/2018, os resultados indicaram que o acesso à tecnologia social parece fortalecer a relação entre a segurança hídrica e alimentar, e a capacidade específica dos agricultores em lidar com os riscos climáticos. Concluímos com lições e recomendações da experiência brasileira que podem ser úteis para atores de outras regiões semiáridas do mundo envolvidos com programas de infraestrutura hídrica.

Palavras-chave: Semiárido brasileiro. Seca. Água. Cisternas. Mudanças climáticas. Adaptação..

\section{INTRODUCTION}

The search for water and food security is an ever-present theme in the discussion of public policies aimed at Brazilian rural areas, especially in the Semi-arid. The region, which occupies $940,000 \mathrm{~km}^{2}$ in nine states, with 27,870,241 inhabitants (MINISTÉRIO DA INTEGRAÇÃO NACIONAL, 2017), is a place where policies aimed at reducing socioeconomic vulnerabilities have a considerable weight in the local historical trajectory, marked by water scarcity and the lowest socioeconomic status Indicators of the country. In 2010, the Human Development Index of the Brazilian Semi-arid municipalities was at the lower limit for "medium" (0.59), far from the national average of "high", but significantly better compared to the "very low" index during the year of 1991 (PNUD; IPEA; FJP, 2016).

In this region, socioeconomic improvements were sought for many years through the "fight against drought" strategy, constructing public/private reservoirs and irrigation projects. Since the first public dam in 1906, the federal government1 has built hundreds of large ones distributed without concern for their effectiveness and impact on the development of family agriculture (MAGALHÃES, 1993). In the post-war era, starting in 1945, the government began to address the drought problem within a regional development strategy (BURSZTYN, 1984), with new institutions linked to hydroelectric power generation, irrigation projects, and bank finance economic activities. Such initiatives aimed to ensure that populations, especially the most vulnerable, had access to water to drink and produce food, not dying of hunger, as observed on several occasions in the past. The Great Drought of 1877/1879 was one of the most impactful in the history of Brazil, causing a great exodus and the death of 500,000 people, more than half of the population of the state of Ceará at the time (GREENFIELD, 2001; SMITH, 1879). Concomitantly with water-related strategies, other approaches focused on alleviating hunger during droughts by delivering emergency baskets, exchanging food for work, and forcing emigration to other states, aiming, in addition to feeding populations, at controlling looting of government food stores. In Ceará, concentration camps for migrants were created in 1932 to imprison the poor and keep them out of the city of the wealthy (RIOS, 2014). In general, until the 1980s, policies of an emergency nature existed to combat drought, without concern about the human right to water and food.

From the 2000s onwards, there was a significant change in the region, when the implementation of a national and integrated policy proposal around the reduction of poverty and food insecurity began through the Zero Hunger Program (2003). The various initiatives associated with the Program have improved access to productive and non-productive resources, income, productive capacity, food and nutrition security, access to other public programs, among other positive impacts. Concerning abundant 
resources, the increase in the means of production has been identified as the critical factor that enables the increase, expansion, and diversification of production for self-consumption (MELLO et al., 2014; MESQUITA et al., 2020). Income transfer through the Family Allowance Program (Bolsa Família) reduced food insecurity in high social and climatic vulnerability (PALMEIRA; SALLES-COSTA; PÉREZ-ESCAMILLA, 2020). However, after 2016 these multidimensional impacts of the initiatives showed a reversal in the face of the country's political and economic scenario (SOUSA et al., 2019), worsening even more in the face of the Covid-19 pandemic (CARVALHO; VIOLA; SPERANDIO, 2021; RIBEIRO-SILVA et al., 2020). In addition to the impacts on health, the pandemic has created several impediments to production and commercialisation by small Brazilian family farmers, increasing poverty and food insecurity, especially in more vulnerable regions such as the Semi-Arid (RIBEIRO-SILVA et al., 2020).

In addition to the region recognisedgnized as a climate hotspot (MARENGO et al., 2020; SIMÕES et al., 2010), there is another challenge of adapting to climate change. According to the IPCC Fifth Report (2014), the average annual temperature increase in the Northeast region should be between $2.0^{\circ} \mathrm{C}$ (RCP scenario 2.6) and $5.0^{\circ} \mathrm{C}$ (RCP scenario 8.5) by 2100 (IPCC, 2014). Such a scenario highlights the need for greater attention to policies with proven positive impacts in the region. Those are mainly built upon the "coexistence with semi-arid" paradigm and have been related to climate adaptation (LINDOSO et al., 2018; MESQUITA et al., 2020; MILHORANCE et al., 2020). In this context, the Cisterns Program stands out for being based on the construction of social technologies for access to water, with several impacts on the food and water security of beneficiaries (CAVALCANTE; MESQUITA; RODRIGUESFILHO, 2020; FERREIRA et al., 2015; VIRGENS et al., 2013), and with the potential to promote changes linked to climate adaptation. Moreover, the Program is a model of how family farming innovations can be transformed into public policy. Through the action of civil society and its dissemination, it reached the level of a national strategy (ARSKY, 2020; MACHADO; ROVERE, 2017; NOGUEIRA, 2017).

Based on the relevance of the Cisterns Program in the themes above and on the region's status as a climate hotspot, this research discusses the perception of beneficiaries and institutional actors about climate change, the impacts of the 2011-2018 drought on the Program's functioning, and its importance in the face of climate change. The two types of adaptive capacities proposed by Eakin et al. (2014) are used for analysis, with generic capacity defined as the assets and capabilities that build the capacity of different systems to face and respond to a variety of stressors, that is, the ability to respond socially, economically and politically, such as income, access to education, health, social capital, physical assets, etc.; and the specific capacity, the ability to anticipate, respond and identify a particular (climatic) risk, developed through the use of climatological information, species resistant to the climate, irrigation, and other practices. Next, the methodological path and the implementation process of the Cisterns Program are presented; followed by the data on the perception of respondents regarding the impact of climate on the Program and the relevance of cisterns; finally, the impact of water infrastructure programs on water and food security is discussed, especially in the context of climate change, and recommendations for water infrastructure programs in semi-arid regions around the world are provided.

\section{METHODOLOGY}

The research was developed in two stages to fill the various areas in which implementing the Cisterns Program develops and materialises. First, beneficiaries and local actors involved with the Program were interviewed in three Brazilian states. In October/2017, 23 farmers were visited in the sub-medium São Francisco river region (Figure 1), in the states of Pernambuco (16 around the municipality of Petrolina) and Bahia (7 in the Paulo Afonso and Juazeiro municipalities); in September/2018, 16 beneficiaries were visited in the state of Ceará (Itapipoca, Santa Quitéria, Itatira, and Quixeramobim), totalling 39 interviewed farmers. On these occasions, when possible, interviews were conducted with local and technical coordinators (10 respondents). Due to the gradual learning about the Program, some additional questions, such as those related to climate, were added in the second fieldwork (Ceará). 
Subsequently, in November/2018, to complement the collected information, face-to-face and remote interviews were conducted with the management teams of the partner institutions involved in the implementation ( 5 respondents) and with the federal government team responsible for the Program (former Ministry of Social Development - SESAN/MDS - 5 interviewees).

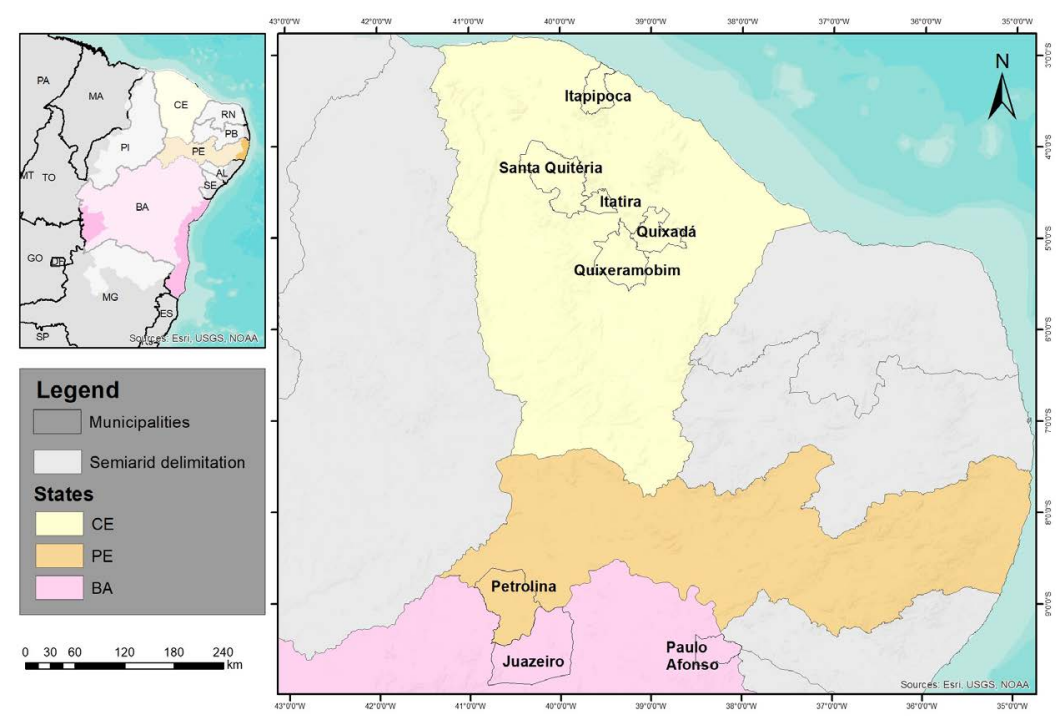

Figure 1 | Study area

Source: The authors

All interviews were qualitative, semi-structured, with sample size determined by data saturation and time available in the field. Data saturation was reached when the research team observed a repeated pattern of responses. According to the data extracted from the statements, those were tabulated and quantified in the case of beneficiaries' data. Due to the limited sample size, percentages are presented only to facilitate the qualitative debate and provide a general context. In general, the research consisted of asking rainfed farmers, technicians, and institutional actors about 1) how the extensive drought-impacted production and the Cistern Program; and 2) the relevance of the water technology in the face of climate change. Additionally, the Research Ethics Committee in Human and Social Sciences at the University of Brasilia $(\mathrm{UnB})$ assessed and approved the research project and its planned execution process.

\subsection{CISTERNS PROGRAM}

The Cisterns Program ${ }^{2}$ has been responsible over the years for expanding the $1^{\text {st }}$ and $2^{\text {nd }}$ water cisterns widely throughout Brazil (COSTA; DIAS, 2013). The $1^{\text {st }}$, known as the consumption cistern, aims to improve access to water for human ingesting, while the $2^{\text {nd }}$ water, the production cistern, aims to support smallscale productive activities. Both social technologies were created with the ultimate goal of helping farmers and other vulnerable populations to achieve food and nutritional security through access to water in quantity and quality suitable for family consumption (e.g., cooking and drinking) and enough water to maintain subsistence farming activities in the backyard or the field.

Briefly, the process for implementing the production cisterns involves four main steps: 1) social mobilisation - includes the process of choosing communities/families, and is the responsibility of the executing entity hired by the ministry. It occurs in partnership with a commission formed by representatives of the municipal secretaries related to health, education, food security, agriculture, and civil society (as members of councils and community leaders). Territorial/regional meetings occur to discuss the project and plan the development of actions; 2 ) select beneficiary families - based on a guiding list sent by the Ministry, obtained from the Federal Government's Single Registry for Social Programs. With the list of 
possible families to be included in the Program, the executing entity presents the project to the local commission, intending to guarantee legality and social control, and the field technicians validate family information in the field; 3 ) registration of families - occurs in an individual or collective meeting (with the community), where beneficiaries are invited to participate in the training. On this occasion is made the collection of extra information for registration in the SIG Cisternas (the program information system); 4) training of families - occurs through two courses: Water Management for Food Production (Gapa) and the Simplified Water for Production System (Sisma). Here, the items delivered in the productive kits are also defined to promote food production, such as seeds, seedlings, and others (SESAN, 2017). Finally, the construction of cisterns occurs with the involvement of beneficiaries, who offer the counterpart of work for the construction of the technology, mobilising members of the family or community in a joint effort scheme, and/or contracting professionals.

\section{RESULTS}

\subsection{RESEARCH DESIGN}

Perceptions about climate change were investigated only in the Ceará fieldwork ( $\mathrm{N}=16)$, where $88 \%$ of respondents mentioned perceiving changes in the climate over the years. Even when asked about the climate in the last 15-20 years, it was noted that the time frame of interviews varied from $10-20$ years (33\%), 2 - 10 years ( $27 \%), 2$ years (13\%), and finally, 40 years ago $(7 \%)$.

Regarding the type of changes, $60 \%$ mentioned temperature was modified, hotter for $78 \%$ of beneficiaries and less desirable for $13 \%$. Regarding rainfall, $93 \%$ noticed changes, among which $14 \%$ described increased rainfall, while $86 \%$ described decreased rainfall (Table 1 ). Precipitation has been more widely spaced, less intense, delayed, or unevenly distributed. Some comments on the perception of climate change were: "it is hotter ...", "rain is weaker, and it is hotter...", "winters were better..." and still, "every year it rained in the winter when I was young ... now it stays longer without rain and hotter ...". And, finally, "20 years ago there was no lack of winter ... it changed a lot, the heat was normal, it wasn't so hot... it was 6 years without raining ... it seems that the sun has turned on...".

Table 1 | Perception about climate

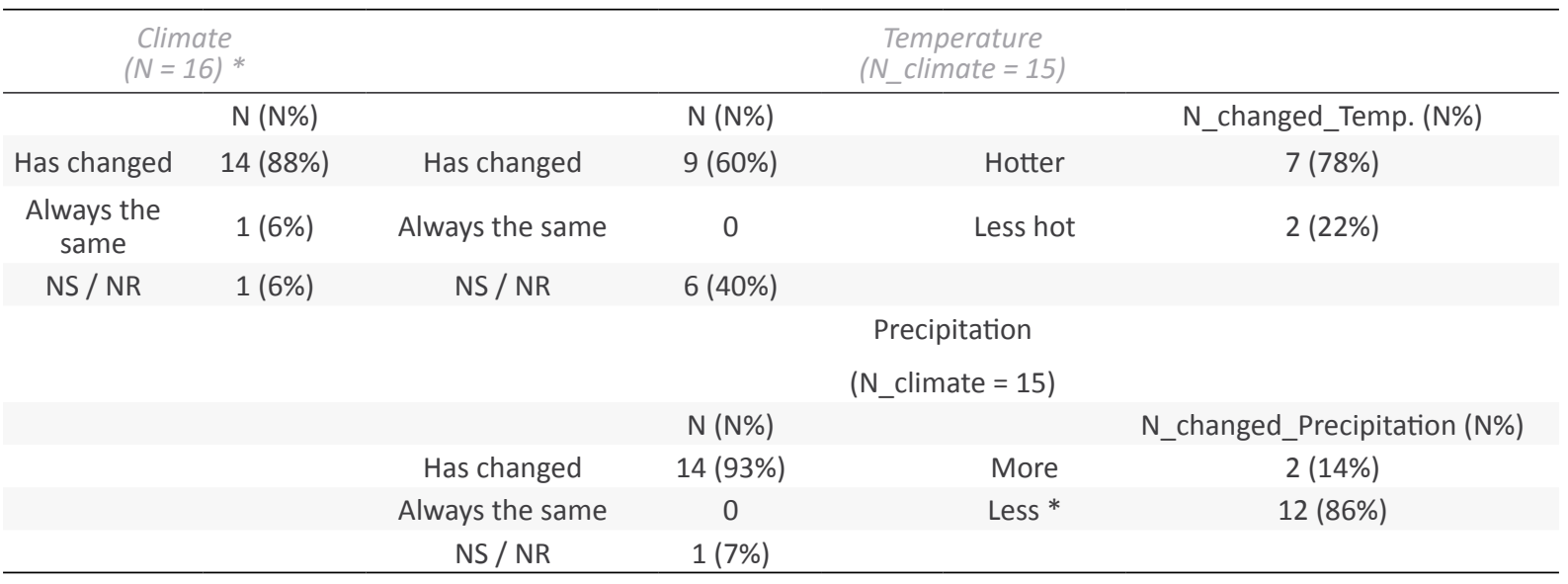

* Spaced rains ( $N=2$ ), less intensity (1), Uneven distribution (1), late (5) and NA (3) Source: Authors.

When asked about what happened to production in extreme periods - heavy rain in a short period of prolonged drought - answers varied and did not follow a pattern. The perceptions were specific to each breeding and crop type and depended on location (Table 2). 
Table 2 | Impacts of extreme droughts and rains

\begin{tabular}{|c|c|}
\hline Droughts & Rain \\
\hline \multicolumn{2}{|c|}{ Crops } \\
\hline Loss of all yard; & Weak plants (excessive rain when flowering); \\
\hline Partial loss of production; & Lower quality production (ex: yellow beans); \\
\hline Dryness to production; & Loss of beans; \\
\hline Burnt plants; & Loss of corn; \\
\hline \multicolumn{2}{|l|}{ Loss of creole seeds; } \\
\hline \multicolumn{2}{|c|}{ Animals } \\
\hline Death of animals; & Wet and cold animals (chicken, sheep); \\
\hline Slimming of animals; & Diseases - e.g., soft hooves; \\
\hline Loss due to increased consumption; & Animal suffering (cold); \\
\hline \multicolumn{2}{|l|}{ Animal suffering (heat); } \\
\hline \multicolumn{2}{|l|}{ Illnesses; } \\
\hline $\begin{array}{l}\text { Behaviour change - hide animals due to the heat/ } \\
\text { sun; }\end{array}$ & \\
\hline
\end{tabular}

In general, farmers emphasised that during the dry season, it was challenging to produce or keep producing: "the heat disturbs... even watering [the plants] it burns because it is very hot... animals are under the trees, they are hiding. ...". In the rainy season, the soil became muddy, becoming hard to produce: "if it rains a lot, beans are no good ... corn prefers dry weather ... but it is better when it is raining more...". Regarding animals, impacts were different depending on the animal: "[when the soil is swamped] plants cannot take it ... goat and chicken do not do well in the rain, pigs are ok...". Finally, another observed: "I don't like the sun, animals suffer ... chickens keep trying to get inside the house...".

According to most technicians and coordinators involved in the implementation, the climate impacted the Cisterns Program. However, one of the interviewed actors pointed out that climate change does not exist and would be a natural phenomenon without connection with short or long drought periods. Among the coordinators who belong to the leading group that believes that the climate changes impacted the Program, it was mentioned that the seven years of drought made it difficult mainly because farmers could not immediately see the results of the implemented technology. Many felt discouraged and ended up not investing in the plantation or animals. Another interviewee recalled that although the Program targets places that generally have eight months without precipitation, the last drought period stood out, as it was related to one of the worst droughts in the previous 50 years.

The rainy season would also have impacted the implementation of the Program in many different ways. During the winter (how the rainy season is named), heavy rains made it difficult to access beneficiary areas and build cisterns due to holes and muddy roads, which at times became insurmountable. Because of this, there were cases of stoppage in the delivery of materials and visits to avoid material and service losses. One of the interviewees noted the difficulty in selecting beneficiaries during the rainy season "... we just had rains and dams are full... then they think the cistern won't be necessary". This perception of a momentary improvement in climate, together with extra costs for families regarding food and lodging for bricklayers, could be inhibiting the decision to participate in the Program. In the dry season, besides the mentioned impacts on beneficiaries, the difficulty accessing water for construction $(9,000$ litres required) and for the partial filling of cisterns (dead volume - so avoids cracking with the thermal variation was reported. Still, the exclusion of certain animals, such as pigs, from the production kit - due to the high water consumption and lack of forage from producers (loss of crop in the previous year); and the loss of seeds and seedlings by suppliers and beneficiaries. Moreover, Program implementation 
could be enhanced if it avoided overlapping with the agricultural calendar. Some beneficiaries stopped participating in training activities (or sending third parties from the family) due to productive activities.

The Program's managers' opinions about climate were aligned with the previous results. The semiarid region had less water availability, generally attributed to climate change and local anthropogenic changes, such as deforestation and desertification. In this sense, climate change could affect the Program in several ways. As the size of social technologies is based on the amount of water necessary for families' consumption and annual climate patterns, changes in water availability and its distribution may generate negative impacts. For example, the 16,000 litres of consumption cisterns was calculated to fill a house with a $40 \mathrm{~m}^{2}$ roof, which, with less rainfall, may no longer be filled as planned. There may also be a need for different types of technology, a change in the same size, or even a need to expand the area of operation and priority audiences. In addition, the team mentioned beneficiaries' frustration. At the same time, technologies were being constructed during the prolonged drought, as farmers were unable to fill cisterns with water and strengthen their coexistence with the Semi-arid. Within the rationale of families, $2^{\text {nd }}$ water cisterns would often be only for domestic consumption in the dry season - the logic would be to use all other available sources until they are exhausted, and then this cistern for non-productive purposes. Finally, it was reported that climate extremes sometimes hampered the Ministry's inspection calendar, but notably by torrential rains.

\subsection{RELEVANCE OF THE CISTERNS PROGRAM IN THE FACE OF CLIMATE CHANGE}

Interviewed farmers believe that cisterns can help people stay in the countryside, allowing them to coexist with the semi-arid region and extreme weather events (67\%). Of these, 50\% reported that water technologies, such as the cisterns, increase the possibility of staying in the countryside ("It is a pity to leave the little things that served us and abandon ..." and "it is already a huge help ... it is an incentive"). Another $19 \%$ said that the Program assists due to production aid, while $15 \%$ said it made it possible to store water. Still, related to the coexistence with the semi-arid, $26 \%$ said that cisterns would only help under the right circumstances, for example, "... if you dare to work", "if you have the motivation to work". One interview participant noted, "Many people do not want [it]... those who want [it] to, fight for it ...".

According to technicians, families were becoming more prepared to live the prolonged periods of drought, having better conditions to face climatic challenges due to the water infrastructure. One of the interviewees pointed out that the implementation of cisterns is an adaptation action due to the concepts and actions addressed in the perspective of coexisting with the semi-arid region. It is also a Program that influences mitigation: "it also has the prospect of restoring [vegetation], [which generates] increases in $\mathrm{CO}_{2}$ sequestration". During the emergency that many municipalities were subjected to, the Program could also prevent rural exodus since it created labour opportunities for bricklayers and others willing to work.

On the part of managers, it was mentioned that for some farmers, the Program would be more of a water reservoir for moments of water scarcity (water from multiple sources besides appreciation), being more for the process of climate adaptation than for the production or insertion in markets. For the Ministry, cisterns have a very close relationship with the issue of climate change, although this plan was only recently included in the planning and debate of the Program. Through this social technology, farmers can better deal with droughts without depending on the "drought industry" (e.g., distribution of water in exchange for votes - (BURSZTYN, 1984), the initiative has even been awarded a prize as a global strategy to combat desertification and land degradation, with impacts related to climatic change (Future Policy Award). From the moment families receive the social technology, they have the possibility and the option to create a different microclimate on the property, with long-term impacts on their production.

These interviewees highlighted that the impacts of $2^{\text {nd }}$ water cisterns on domestic water management in times of drought showed that it is essential to expand the water potential of families, with underground 
dams, trench barriers, and other small infrastructures, since many families with cistern managed not returning to extreme situations due to the drought.

Given this perspective, the Program's focus, which previously was in the area of food security and water security, would now be migrating to climate change due to the National Policy for Adaptation to Climate Change (Law No. 12,187/2009) and also due to the need of opening new funding opportunities (especially for production cisterns that has a lower priority and budget, when compared to the $1^{\text {st }}$ water). In other biomes in Brazil, this would also be of great importance in the context of climate change. In the Amazon, for example, cisterns would be seen as a way of enabling livelihoods with health and sanitation, with treated water serving for the hygiene of products produced, consumed, and traded, access to sanitary structures (bathrooms), and potentially more significant conservation of the environment.

\section{DISCUSSION}

The $2^{\text {nd }}$ Water Cisterns Program was created to promote access to water for food production through the implementation of low-cost and straightforward social technologies. This modality of the Program was aimed at increasing the water availability of family farmers so that they produce food, either for self-consumption or for the sale of surpluses, guaranteeing, in addition to water security, food security. In these aspects, some studies indicate that the Program has contributed to what it was created for (CAVALCANTE; MESQUITA; RODRIGUES-FILHO, 2020; FERREIRA et al., 2015; VIRGENS et al., 2013). In general, research indicates that farmers have increased the use of agroecological production methods, some because they already had the knowledge passed down between generations, and others because they learned in the training that is part of the implementation stages of the Program (FERREIRA et al., 2015). There is an indication that in the state of Pernambuco, the Program has been constituted as an essential tool for improving food security and strengthening the identity bonds of families (FERREIRA et al., 2015). The production of fruits, through the water of production cisterns, also helps in meeting the daily nutritional needs of families, especially those of vitamin C (ARAÚJO; BRITO; CAVALCANTI, 2011). Furthermore, Cavalcante et al. (2020) point to positive impacts on food security and the ability to adapt through social learning, as beneficiaries described greater confidence in their knowledge and skills as a result of courses, in addition to contentment due to the storage of water and increases in production and sales of the surplus. The effects of the Program's implementation methodology are also highlighted by Arsky (2020), who discusses the role of "experimenting farmers", producers who started to exchange experiences and shared knowledge with other farmers.

Due to the multiple impacts, the Cisterns Program, in general, was seen as an adaptation project by all beneficiaries, coordinators, and technicians interviewed here, as it helps farmers to live with more quality in prolonged periods of drought. It was also considered an essential factor for people persisting in rural areas. However, the various positive impacts can be compromised due to increased drought periods, especially climate change. As mentioned, most of the problems in the Brazilian semi-arid region stem from the lack of water, and climate change will contribute to worsening this situation. Recent studies indicate that the last multi-annual drought period 2012-2017 was the longest in the previous 50 years (BRITO et al., 2018; MARENGO et al., 2020; MARENGO; CUNHA; ALVES, 2016). This came to impact the performance of agricultural activities (SANTANA; SANTOS, 2020) and the water supply for priority uses (LIMA; MAGALHÃES, 2018). This context of water scarcity led to several impacts on the Cisterns Program, as can be seen in the results. Other programs in Brazil and around the world have also been impacted by the climate, such as the Food Acquisition Program (MESQUITA; BURSZTYN, 2017), the National Program for Strengthening Family Agriculture (Pronaf) (LIMA; MAGALHÃES, 2018), and the Millennium Villages, a school meal program in Ethiopia (REMANS et al., 2010).

Farmers also reported a perception of climate change, with almost all respondents mentioning that climate had changed somehow. For them, increases in temperature and precipitation regime changes 
were noticeable, with the concentration of rainfall periods (with a significant time spacing between events) and less frequent rainfall being often highlighted.

These have led to various reactive adaptation strategies, such as creating ways of protecting animals and changing planting times, many of which are traditional handling techniques practised by farmers from other countries worldwide. For example, in an arid zone of Myanmar, it was observed that, given the impediments to production caused by climate changes, farmers were strengthening and reviving the use of conventional water management practices, such as rainwater collection and similar (SWE et al., 2015). As noted by Mesquita et al. (2020), ex-post strategies, adjustments implemented after climatic shocks and more focused on facing its impacts (ABID et al., 2020; IPCC et al., 2001; SHIFERAW et al., 2014) are mainly used in the face of climatic adversities in Semi-arid Brazil, although ex-ante (before the shocks) adaptation is more advantageous since avoids possible assets and resources losses, and even irreversible damage of farmers' capital related to continuous losses (HANSEN et al., 2004; MESQUITA; MILHORANCE, 2019).

As mentioned, climate can also sometimes influence farmers' decisions to accept participation in the Program. Thus, we underline there is not only an impact of droughts in water infrastructure programs due to climate change, but also of torrential rains, and both scenarios should be considered when discussing the inclusion of beneficiaries, the implementation processes, the execution schedule, and the scenario of the water-related programs within a climate change context. It is worth mentioning that actions that count with the participation of beneficiaries must consider the agricultural calendar and the unavailability of farmers in the initial period of rains and planting. Finally, it is worth stating the importance of another role assigned to the Program - of occupying the local workforce, subject to an exodus, in a context of climatic emergency. From 2013 to 2016, 48 million people were affected by droughts in Brazil, 6 times more than floods. 4,824 drought events associated with human damage were quantified, almost 3 times more than flood events $(1,738)$. 2016 was the most critical year in drought impacts on the population (ANA, 2017). Historically, several programs have used this rationale of allowing workers during drought times in Semi-arid Brazil. Still, one must realise the differences between the past and present models and the role that cisterns could play during these times. The work carried out by farmers represents an investment in family capital, with the prospect of helping to maintain producers in rural areas over the generations; it provides a personal, non-transferable, and non-communal asset, unlike the historical construction of dams and roads carried out by work fronts in the significant droughts.

\subsection{CISTERNS STRENGTHENING THE RELATIONSHIP BETWEEN WATER AND FOOD SECURITY AND GENERIC AND SPECIFIC CAPACITIES}

Social technologies for water access are symbolic in discussing the importance of social programs for farmers facing extreme drought, thus guaranteeing some water security and food and nutritional security. Even if cisterns and other technologies are not filled with rainwater, these nevertheless represent a structure that helps to face difficulties related to water scarcity, as they can be supplied with water trucks purchased with their income (since only the consumption cistern is provided by a government water truck program - Operação Carro-Pipa), with piped water, or drawn from wells, weirs, and other sources.

In this regard, the Cisterns Program can be seen as a connection of the water-food nexus, since that at the same time that allows greater water security; it also seeks to increase the productive capacity and food security of farmers. This concept is based on the inseparability between water and food, and from the rationale that any changes in water quality and availability affect (and are affected by) production systems, that is, there are several interdependencies, synergies, and trade-offs between the two, in addition to the various interconnections with climate, energy, access to land, among other factors (BREARS, 2015; LAIO; RULLI; SUWEIS, 2017). 
Still, several aspects have to be observed when defending such an argument since factors other than access to water are linked to productive capacity and even to food security as a whole. In this relationship, access to extension and education services can exert some influence. For example, the lack of adequate water management, together with the lack of technical assistance, sometimes leads to the erroneous feeding of animals and their lower productivity (BURNEY et al., 2014). Through rural extension or education, the importance of access to knowledge has already been highlighted for the success of initiatives such as the Cisterns Program (CAVALCANTE; MESQUITA; RODRIGUES-FILHO, 2020). Mesquita et al. (2021) highlighted that technical assistance and rural extension technicians (Ater, in the Brazilian acronym) have the role of street-level bureaucrats (LIPSKY, 2010) since their activity directly affects how programs, such as the Cisterns, are implemented at the local level. The Program, when implemented locally by an executor who aims for agroecological production, also contributes to the recovery and preservation of the Caatinga Biome, strengthening the relationships between the humannature system, and mitigating climate change, even if in a limited way, as it inhibits deforestation in the Biome. The role of technicians is crucial for disseminating agricultural techniques and climate information for better adaptation to climate change in other arid and semi-arid locations around the world (SWE et al., 2015).

From the perspective of climate change, the Program seems to be able to minimise the extreme and unwanted responses of farmers in drought events, such as abandonment of areas, migrations, among others, since food insecurity (MILAN; RUANO, 2014), and socioeconomic and educational level are related to this behaviour (DELAZERI; DA CUNHA; OLIVEIRA, 2021). The Program, by strengthening income growth and access to technical knowledge, can influence the family's decision to emigrate or not in the face of shocks.

Although the cisterns influence more in specific capacity-building, beneficiaries are also participants in the Family Allowance Program, an initiative that deals with generic capacities and structural deficits related to climate vulnerability. In 2010, this program aided around $54.3 \%$ of the population in the Brazilian Semi-arid region (SILVA; PAES, 2019). For Brazilian semi-arid, specific capacities were defined as

manifestations of the ability to respond to and manage an identified climate hazard (e.g., drought emergency response plans, hurricane warning systems, climate forecasting, design and construction of protective infrastructures such as irrigation and public works such as reservoirs (LEMOS et al., 2016a, p. 171).

In this study, using food insecurity as a proxy for vulnerability to climate change, two risk management strategies were identified as most relevant - the Crop Guarantee Program (Seguro Safra), insurance against crop failure, and access to irrigation, both important in modulating food insecurity. For the latter strategy, an association between high levels of generic capacity and this specific capacity was observed, suggesting that the most significant vulnerability reduction results are found when farmers invest additional income in strengthening specific capacity (irrigation). According to Eakin et al. (2014) and Lemos et al. (2016b), even if there is a particular capacity, a minimum level of generic capacity is necessary to manage risks. In this sense, it is worth emphasising the relevance of the researched Program in the construction of sustainable irrigated production systems with water from the cisterns (GONÇALVES; RIOS; CARVALHO, 2013). Obermaier et al. (2009) emphasise that sustainable irrigation techniques are essential to improve adaptive capacity in semi-arid areas of Brazil.

However, one should also think of the limited role of large-scale irrigation as a strategy to strengthen specific capacity (HERWEHE; SCOTT, 2018) to be promoted in an environment that suffers from increasingly extreme droughts, especially when thinking about the implementation of a broad irrigation strategy for the semi-arid region. Even farmers living in the banks of canals and rivers, like many in our study area in the São Francisco Basin, have suffered the consequences of droughts (SOBRAL et al., 2018). In 2015 and 2016, the Sobradinho reservoir reached less than $20 \%$ of the total volume (MILHORANCE et al., 2019). This worsened conflicts in the region because power 
generation prevails as a priority despite the high irrigation demands, causing losses to farmers and riverside dwellers and hindering the supply of food to urban areas (NOBRE et al., 2019). The already high global demand for water, together with the fact that irrigation is one of the strategies used for adaptation, will lead to more disputes in the face of climatic changes (HERWEHE; SCOTT, 2018).

Here we can see the relevance of the Cisterns Program, strengthening the specific capacity of farmers in dealing with climatic risks through the possibility of storing water for prolonged periods and developing small irrigation projects in their property. This goes against the extensive irrigation projects, which have already been shown to increase farmers' vulnerability during prolonged droughts (GUJJA et al., 2009; YU et al., 2009). The role of the more efficient irrigation techniques with less need for manual labour is highlighted by Herwehe and Scott (2018). In the study, along with the diversification of income sources, efficient irrigation systems, such as micro-sprinkler or drip irrigation (usually received through government programs), were related to mitigating the impacts of drought on family farmers' production Brazilian Semi-arid. However, it is worth noting that the appeal for water conservation was not the main rationale used by farmers. Still, rather than reducing manual labour and soil degradation, water conservation and saving for times of extreme drought was seen as a lateral benefit. Environmental management practices, including water management through rainwater collection, are a common risk reduction strategy in the face of climate change around the world (BURNHAM; MA, 2016).

Several productive kits that complement the social technology and are selected according to local needs include simplified irrigation systems, such as drip hoses. Therefore, the Program, besides being an inducer of the water-food nexus, can strengthen critical specific capacities in a climate change context, especially when aligned with other policies, such as those under the Zero Hunger Program. As Lemos (2016b) points out, the idea is that structural deficits linked to generic capacities and climate risks can be addressed together in favour of greater adaptive capacity through synergies between programs related to climate adaptation and rural development.

\section{CONCLUSIONS}

From the perceptions of farmers and institutional actors involved with the Cisterns, it was possible to understand how the extensive drought period impacted production systems and how the Program has been helping to increase adaptive capacity. Access to the Program, together with others in which beneficiaries participate (such as the Family Allowance Program), can be seen as a means of strengthening the relationship between water and food security and the generic and specific capacity of farmers through synergies between impacts directly related to poverty reduction and others linked to climate adaptation. As noted, climate extremes have caused impacts in semi-arid areas in Brazil and other developing countries (Ex: Myanmar, Swe et al. 2015), influencing the successful implementation of social programs. Based on this, we conclude with some suggestions for water infrastructure programs in semi-arid regions worldwide.

First, related to climate scenarios, the entire climate dimension should be considered during the planning of programs as a way to achieve an adaptive social protection strategy, making it more resilient to the most diverse types of shocks, including current and future climate variability effects (BÉNÉ; CORNELIUS; HOWLAND, 2018; BÉNÉ; NEWSHAM, 2011; DAVIES et al., 2009). Within this framework, great attention is paid to the need of integrating social protection, with risk reduction and adaptation to climate change, achieved through the improvement of knowledge and data on risks and needs, as well as on the success of specific strategies, increasing the capacity of programs and beneficiaries to respond to shocks (BOWEN et al., 2020).

Programs' planning must also consider extreme rain events, considering the lifespan and the construction processes of water infrastructures, aiming to construct additional structures (ex: barriers, 
dams) that store spare volume during large rain events. Such importance is even more significant given the diverse uses of these technologies. Here, there were reports of domestic use (for cooking, washing) of the water stored in the $2^{\text {nd }}$ water cistern, which indicates that there is still a deficiency in the stock for home use, possibly reducing the program impact on production. Implementing programs must consider climatic patterns and regions' projections, observing planting periods of the leading regional crops. Productive kits, delivered along with social technologies, also need to be considered in this context since the loss of inputs with extremes of climate was observed. In extreme climate situations, technicians' visit is also essential, being an opportunity to address other less practical issues, such as the diffusion of climate knowledge. For this, guidance and training on the impact of climate change and mitigation and adaptation actions in the rural area are essential.

Regarding this process, it is suggested that all programs in areas considered climate hotspots include the preparation of courses and materials of easy assimilation aimed at expanding climate knowledge of different actors, in addition to beneficiaries. For the latter, more excellent expertise about climate change can influence planning and early adaptation to future events, including reducing the refusal to join programs during rainy seasons (due to misperception that drought is gone). Due to the importance of soil conservation, together with that of collecting water and adjusting production to droughts (drought-resistant species) to adapt to climate change in more arid areas (KALUNGU; LEAL FILHO, 2018), such materials should expand knowledge about the benefits of soil and biome conservation, and agroecological practices in the face of climate change. Still, discussing extreme climate impacts on animals and plants and ways of adapting should also be included. This process can be combined with other strategies, such as the diffusion of climate knowledge through booklets and lectures in countryside schools (LITRE et al., 2017). Water infrastructure programs, aligned with the inclusion of small, efficient irrigation systems, also favour savings of farmers' time and less soil degradation, as demonstrated by Herwehe and Scott (2018).

And, finally, in the scope of program planning, one must think about the articulation of water infrastructure programs with other strategies (ex: water reuse programs, rural insurance, school meals, etc.), so positive synergies can be exploited as a result of better planning (MILHORANCE et al., 2019, 2020). Despite the sometimes-limited effect of more drought-oriented programs on strengthening adaptive capacity, the active participation of farmers, together with broader poverty alleviation programs with which the same populations are associated, can address both specific and generic needs, promoting long-term changes necessary in a scenario of climate change.

\section{NOTES}

1 | 1906 - Ifocs (Federal Inspectorate of Works against Drought); in 1909 became locs (Inspectorate of Works against Drought); and in 1945, Dnocs (National Department for Works Against Drought). [2] Law no 12.873 / 2013 , regulated by Decree no 9.606/2018.

\section{ACKNOWLEDGEMENTS}

This work is part of research activities of Rede Clima (Regional Development sub-network) and INCT/ Odisseia (Observatory of socio-environmental dynamics: sustainability and adaptation to climate, environmental and demographic changes) under the National Institutes of Science and Technology Program (Call INCT - MCTI/CNPq/Capes/FAPs n.16/2014). Acknowledgements to Capes (Coordination for the Improvement of Higher Education Personnel), CNPq (National Council for Scientific and Technological Development), and FAP-DF (Research Support Foundation of the Federal District) for research funding, and the former Ministry of Social Development (MDS) for funding and partnership during data collection. 


\section{REFERENCES}

ABID, M. et al. Ex-ante and ex-post coping strategies for climatic shocks and adaptation determinants in rural Malawi. Climate Risk Management, v. 27, p. 100-200, 1 jan. 2020.

AGÊNCIA NACIONAL DE ÁGUAS. Conjuntura dos recursos hídricos no Brasil 2017: relatório pleno. Brasília, DF: Agência Nacional de Águas, 2017.

ARAÚJO, J. O. DE; BRITO, L. T. DE L.; CAVALCANTI, N. D. B. Água de chuva armazenada em cisterna pode incrementar a qualidade nutricional da dieta das famílias. Resumos do VII CONGRESSO BRASILEIRO DE AGROECOLOGIA. Anais [...]. Fortaleza, CE, 2011.

ARSKY, I. D. C. Os efeitos do Programa Cisternas no acesso à água no semiárido. Desenvolvimento e Meio Ambiente, v. 55, 17 dez. 2020

BÉNÉ, C.; CORNELIUS, A.; HOWLAND, F. Bridging Humanitarian Responses and Long-Term Development through Transformative Changes - Some Initial Reflections from the World Bank's Adaptive Social Protection Program in the Sahel. Sustainability, v. 10, n. 6, p. 1697, 23 maio 2018.

BÉNÉ, C.; NEWSHAM, A. Social Protection and Climate Resilience. Report from an international workshop, Addis Ababa. [s.l.] World Bank, 2011.

BOWEN, T. et al. Adaptive Social Protection: building resilience to shocks. [s.I.] Washington, DC: World Bank, 2020.

BREARS, R. C. The circular economy and the water-food nexus. Future of Food: Journal on Food, Agriculture and Society, v. 3, n. 2, p. 53-59, 2015.

BRITO, S. S. B. et al. Frequency, duration and severity of drought in the Semiarid Northeast Brazil region: frequency, duration and severity of drought in the brazilian semiarid. International Journal of Climatology, v. 38, n. 2, p. 517-529, fev. 2018.

BURNEY, J. et al. Climate change adaptation strategies for smallholder farmers in the Brazilian Sertão. Climatic Change, v. 126, n. 1-2, p. 45-59, set. 2014.

BURNHAM, M.; MA, Z. Linking smallholder farmer climate change adaptation decisions to development. Climate and Development, v. 8, n. 4, p. 289-311, 7 ago. 2016.

BURSZTYN, M. O poder dos donos: planejamento e clientelismo no Nordeste. Petrópolis: Vozes, 1984.

CARVALHO, C. A. DE; VIOLA, P. C. DE A. F.; SPERANDIO, N. How is Brazil facing the crisis of Food and Nutrition Security during the Covid-19 pandemic? Public Health Nutrition, v. 24, n. 3, p. 561-564, fev. 2021.

CAVALCANTE, L.; MESQUITA, P. S.; RODRIGUES-FILHO, S. $2^{\text {nd }}$ Water Cisterns: social technologies promoting adaptive capacity to Brazilian family farmers. Desenvolvimento e Meio Ambiente, v. 55, 17 dez. 2020.

COSTA, A. B.; DIAS, R. DE B. Estado e sociedade civil na implantação de políticas de cisternas. In: Tecnologia Social e Políticas Públicas. [s.I.] São Paulo: Instituto Pólis. Brasília: Fundação Banco do Brasil, 2013. p. 33-63.

DAVIES, M. et al. Climate Change Adaptation. Disaster Risk Reduction and Social Protection: complementary roles in agriculture and rural growth? IDS Working Papers, v. 2009, n. 320, p. 01-37, fev. 2009.

DELAZERI, L. M. M.; DA CUNHA, D. A.; OLIVEIRA, L. R. Climate change and rural -urban migration in the Brazilian Northeast region. GeoJournal, 5 jan. 2021.

EAKIN, H. C.; LEMOS, M. C.; NELSON, D. R. Differentiating capacities as a means to sustainable climate change adaptation. Global Environmental Change, v. 27, p. 1-8, jul. 2014.

FERREIRA, E. P. et al. Cisternas de produção para melhoria da qualidade de vida no semiárido do estado de Pernambuco. Revista Verde de Agroecologia e Desenvolvimento Sustentável, v. 10, n. 4, p. 13, 16 out. 2015. 
GONÇALVES, H. V. B.; RIOS, M. L.; CARVALHO, A. DE. Avaliação do manejo de agroecossistemas familiares atendidos pelo programa p1+ 2 na comunidade Inácio João, município de Caém, Bahia. ENCICLOPÉDIA BIOSFERA. Centro Científico Conhecer. Goiânia, v. 9, n. 16, p. 17, 2013.

GREENFIELD, G. M. The Realities of Images: imperial Brazil and the great drought. American Philosophical Society, v. 91, n. 1, p. 170, 2001.

GUJJA, B. et al. Adapting to climate change in the Godavari River basin of India by restoring traditional water storage systems. Climate and Development, v. 1, n. 3, p. 229-240, nov. 2009.

HANSEN, J. W. et al. Climate Variability and the Millennium Development Goal Hunger Targ. p. 27, 2004.

HERWEHE, L.; SCOTT, C. A. Drought adaptation and development: small-scale irrigated agriculture in northeast Brazil. Climate and Development, v. 10, n. 4, p. 337-346, 19 maio 2018.

IPCC et al. (Ed.). Climate change 2001: impacts, adaptation, and vulnerability. Contribution of Working Group II to the third assessment report of the Intergovernmental Panel on Climate Change. Cambridge, UK. New York: Cambridge University Press, 2001.

IPCC. Summary for Policymakers. In: Climate Change 2014: mitigation of climate change. Working Group III Contribution to the IPCC Fifth Assessment Report. Cambridge: Cambridge University Press., 2014.

KALUNGU, J. W.; LEAL FILHO, W. Adoption of appropriate technologies among smallholder farmers in Kenya. Climate and Development, v. 10, n. 1, p. 84-96, 2 jan. 2018.

LAIO, F.; RULLI, M. C.; SUWEIS, S. The challenge of understanding the water-food nexus complexity. Advances in Water Resources, v. 110, p. 406-407, 1 dez. 2017.

LEMOS, M. C. et al. Linking development to climate adaptation: leveraging generic and specific capacities to reduce vulnerability to drought in NE Brazil. Global Environmental Change, v. 39, p. 170-179, jul. 2016 a.

LEMOS, M. C. et al. Advancing metrics: models for understanding adaptive capacity and water security. Current Opinion in Environmental Sustainability, v. 21, p. 52-57, ago. 2016 b.

LIMA, J. R.; MAGALHÃES, A. R. Secas no Nordeste: registros históricos das catástrofes econômicas e humanas do século 16 ao século 21. Parcerias Estratégicas, v. 23, n. 46, p. 191-212, 2018.

LINDOSO, D. et al. Harvesting Water for Living with Drought: insights from the Brazilian human coexistence with semi-aridity approach towards achieving the sustainable development goals. Sustainability, v. 10, n. 3, p. 622, 28 fev. 2018.

LIPSKY, M. Street-level bureaucracy: dilemmas of the individual in public services. [s.I.] Russell Sage Foundation Publications, 2010.

LITRE, G. et al. O desafio da comunicação da pesquisa sobre riscos climáticos na agricultura familiar: a experiência de uso de cartilha educativa no semiárido nordestino. Desenvolvimento e Meio Ambiente, v. 40, 30 abr. 2017.

MACHADO, L.; ROVERE, E. The Traditional Technological Approach and Social Technologies in the Brazilian Semiarid Region. Sustainability, v. 10, n. 2, p. 25, 22 dez. 2017.

MAgAlHÃES, A. R. Drought and Policy Responses in the Brazilian Northeast. In: Drought Assessment, Management, and Planning. [s.I.] Kluwer Academic Publishers, 1993. p. 1-18.

MARENGO, J. A. et al. Assessing drought in the drylands of northeast Brazil under regional warming exceeding $4^{\circ} \mathrm{C}$. Natural Hazards, 16 jun. 2020.

MARENGO, J. A.; CUNHA, A. P.; ALVES, L. M. A seca de 2012-15 no semiárido do Nordeste do Brasil no contexto histórico. p. 6, 2016. 
MELLO, J. et al. A inclusão produtiva rural do Brasil sem Miséria: estratégias e primeiros resultados. In: O Brasil sem Miséria. Brasília - DF: Ministério do Desenvolvimento Social e Combate à Fome, 2014.

MESQUITA, P. et al. Impacts of the Fomento Program on Family Farmers in the Brazilian Semi-Arid and its relevance to climate change: a case study in the region of Sub medio São Francisco. Sustentabilidade em Debate, v. 11, n. 1, p. 211-225, 30 abr. 2020.

MESQUITA, P.; MILHORANCE, C. Facing food security and climate change adaptation in semi-arid regions: lessons from the Brazilian Food Acquisition Program. Sustentabilidade em Debate, v. 10, n. 1, p. 30-42, 30 abr. 2019.

MESQUITA, P. S.; BURSZTYN, M. Food acquisition programs in the Brazilian semi-arid region: benefits to farmers and impacts of climate change. Food Security, v. 9, n. 5, p. 1041-1051, out. 2017.

MESQUITA, P. S.; MILHORANCE, C.; CAVALCANTE, L. O papel dos burocratas de nível da rua na implementação de políticas intersetoriais: articulação dos programas sociais e de acesso à água no semiárido brasileiro. Confins. Revue franco-brésilienne de Géographie / Revista franco-brasileira de Geografia, n. 50, 28 maio 2021.

MILAN, A.; RUANO, S. Rainfall variability, food insecurity and migration in Cabricán, Guatemala. Climate and Development, v. 6, n. 1, p. 61-68, 2 jan. 2014.

MILHORANCE, C. et al. O desafio da integração de políticas públicas para a adaptação às mudanças climáticas no semiárido brasileiro. Revista Brasileira de Climatologia, v. 24, 9 maio 2019.

MILHORANCE, C. et al. Unpacking the policy mix of adaptation to climate change in Brazil's semiarid region: enabling instruments and coordination mechanisms. Climate Policy, p. 1-16, 22 abr. 2020.

MINISTÉRIO DA INTEGRAÇÃO NACIONAL. 115. Aprova a Proposição n 113/2017, que acrescenta municípios à relação aprovada pela Resolução Condel n 107, e 27 de julho de 2017. 23 nov. 2017.

NOBRE, P. et al. Solar smart grid as a path to economic inclusion and adaptation to climate change in the Brazilian Semiarid Northeast. International Journal of Climate Change Strategies and Management, v. 11, n. 4, p. 499517, 19 ago. 2019.

NOGUEIRA, D. Segurança hídrica, adaptação e gênero. Sustentabilidade em Debate, v. 8, n. 3, p. 22-36, 29 dez. 2017.

OBERMAIER, M. et al. Adaptation to Climate Change in Brazil: the pintadas pilot project and multiplication of best practice examples through dissemination and communication networks. p. 7, 2009.

PALMEIRA, P. A.; SALLES-COSTA, R.; PÉREZ-ESCAMILLA, R. Effects of family income and conditional cash transfers on household food insecurity: evidence from a longitudinal study in Northeast Brazil. Public Health Nutrition, $v$. 23, n. 4, p. 756-767, mar. 2020.

PNUD; IPEA; FJP. Desenvolvimento humano nas macrorregiões brasileiras: 2016. Brasília - DF: [s.n.].

REMANS, R. et al. Addressing undernutrition and climate change in the millennium villages: enhancing resilience of rural communities. SCN News, n. 38, p. 71-77, 2010.

RIBEIRO-SILVA, R. DE C. et al. Covid-19 pandemic implications for food and nutrition security in Brazil. Ciência \& Saúde Coletiva, v. 25, p. 3421-3430, 28 ago. 2020.

RIOS, K. S. Isolamento e poder: Fortaleza e os campos de concentração na seca de 1932. Fortaleza, CE: Imprensa Universitária, 2014.

SANTANA, A. S.; SANTOS, G. Impactos da seca de 2012-2017 na região semiárida do Nordeste: notas sobre a abordagem de dados quantitativos e conclusões qualitativas. p. 12, 2020.

SESAN. Instrução Operacional Sesan n 15, de 19 de dezembro de 2017. Modelo da Tecnologia Social de Acesso à água ${ }^{\circ}$ 21. Cisterna-calçadão de 52 mil litros. Brasília: Diário Oficial da União, de 20 de dezembro de 2017. 20 dez. 2017 
SHIFERAW, B. et al. Managing vulnerability to drought and enhancing livelihood resilience in sub-Saharan Africa: technological, institutional and policy options. Weather and Climate Extremes. High Level Meeting on National Drought Policy, v. 3, p. 67-79, 1 jun. 2014.

SILVA, E. S. DE A. DA; PAES, N. A. Bolsa Família Programme and the reduction of child mortality in the municipalities of the Brazilian semiarid region. Ciência \& Saúde Coletiva, v. 24, p. 623-630, fev. 2019.

SIMÕES, A. F. et al. Enhancing adaptive capacity to climate change: the case of smallholder farmers in the Brazilian semi-arid region. Environmental Science \& Policy, v. 13, n. 8, p. 801-808, dez. 2010.

SMITH, H. Brazil, the amazons and the coast. New York: Charles Scribner's Sons, 1879.

SOBRAL, M. DO C. et al. Impacto das mudanças climáticas nos recursos hídricos no submédio da bacia hidrográfica do Rio São Francisco - Brasil. Rede - Revista Eletrônica do Prodema, v. 12, n. 2, 2018.

SOUSA, L. R. M. DE et al. Food security status in times of financial and political crisis in Brazil. Cadernos de Saúde Pública, v. 35, 29 jul. 2019.

SWE, L. M. M. et al. Farmers' perception of and adaptation to climate-change impacts in the Dry Zone of Myanmar. Climate and Development, v. 7, n. 5, p. 437-453, 20 out. 2015.

VIRGENS, M. C. DAS et al. Cisternas de enxurradas como alternativa para a agricultura familiar. Enciclopédia Biosfera, v. 9, n. 16, p. 78, 18 nov. 2013.

$\mathrm{YU}, \mathrm{X}$. et al. Freshwater management and climate change adaptation: experiences from the central Yangtze in China. Climate and Development, v. 1, n. 3, p. 241-248, nov. 2009. 